\title{
THE EARLY HISTORY OF NERVE REGENERATION BEGINNING WITH CRUIKSHANK'S OBSERVATIONS IN 1776
}

\author{
by
}

\section{SIDNEY OCHS*}

THAT NERVE could regenerate was first indicated by William Cumberland Cruikshank (1745-1800) just two hundred years ago, in 1776. He cut a section from the vagus nerve of dogs and after some weeks found what he believed to be a new growth of nerve filling in the gap. John Hunter, for whom Cruikshank then worked as a dissector, sent Cruikshank's paper describing his experiments on nerve regeneration to the Royal Society. The paper was not, however, published at the time, apparently because the editors were sceptical regarding the nature of the regenerating material; whether it was truly nerve or a growth of non-neural tissue. Their reservations were later overcome and the paper finally published in $1795 .^{1}$ It appeared just before a closely similar paper on regeneration by Haighton ${ }^{2}$ which seemed to substantiate the phenomenon earlier seen by Cruikshank. Years later, Cruikshank gave what he presumed was the reason for the delay in publication:

These experiments were made for another purpose, by which I discovered the independence of the heart's motion on its nerves, as well as the reunion after division, and the regeneration after loss of substance in the nerves themselves. I wrote a paper on this subject a long time since, which the late Mr. John Hunter, to whose memory and talents I am always proud to pay my tribute, presented to the Royal Society, but it was not then printed; I think Mr. Hunter gave me for a reason, that it controverted some of Haller's opinions, who was a particular friend of Sir John Pringle, then President of the Royal Society. Another gentleman has lately made experiments on the same subject, and has also presented them to the Royal Society. Upon hearing these read at the Society, Mr. Home, [later Sir Everard Home, John Hunter's brother-in-law] with that intelligence of anatomical subjects that distinguishes his character, and the school he was bred in, remembered my experiments, though made nearly twenty years ago. The present President of the Royal Society, who, fortunately for mankind, prefers the promulgation of science to Haller or any other man, on being made acquainted with this circumstance, has caused the paper on these experiments to be printed in the Philosophical Transactions for 1794."

"Sidney Ochs, Ph.D., Department of Physiology, Indiana University School of Medicine, 1100 West Michigan Street, Indianapolis, Indiana 46202, U.S.A.

${ }^{1} \mathrm{~W}$. Cruikshank, 'Experiments on the nerves, particularly on their reproduction; and on the spinal marrow of living animals', Phil. Trans. R. Soc., 1795, 85: 512-519 (abridged version).

$2 \mathrm{~J}$. Haighton, 'An experimental inquiry concerning the reproduction of nerves', ibid., 1795, 85: 519-525 (abridged version).

J. Young (1889), introduction to Catalogue of the pathological specimens in the Glasgow Royal Infirmary, prepared by A. J. Marshall, and J. A. G. Burton, University of Glasgow, 1962, p. xlvi. Quotation from a footnote with reference to Cruikshank's book Experiments on the insensible perspiration of the human body, London, G. Nicol, 1795, p. 88. 


\title{
Sidney Ochs
}

In this paper we will trace the history of nerve regeneration beginning with Cruickshank's observations. It will be shown how the early ideas of regeneration depended upon the view taken of the neuron; whether it was considered to be the single entity as we know it today, or composed of two closely related but separate parts, the cell body and nerve fibre.

\section{THE EARLY STUDIES OF REGENERATION MADE USING VAGUS NERVES}

It was recognized by the seventeenth century that bilateral section of the vagal nerves in the neck led within a few days to the death of an animal. A description of the effects of cutting the "wandering" nerve, the early English term used for the vagus nerve was given by Willis:

\begin{abstract}
We once made a tryal of the following Experiment upon a living Dog. The skin about the Throat being cut long-ways, and the Trunk of both the wandring pair being separated apart, we made a very strict Ligature; which being done, the Dog was presently silent, and seemed stunned, and suffered about the Hypochondria convulsive motions, with a great trembling of the Heart. But this affection quickly ceasing, afterwards he lay without any strength of lively aspect, as if dying, slow and impotent to any motion, and vomiting up any food that was given him: nevertheless his life as yet continued, neither was it presently extinguished after those nerves were wholly cut asunder; but this Animal lived for many days, and so long, till through long fasting, his strength and spirits being worn out, he died. ${ }^{5}$
\end{abstract}

Unfortunately, the survival time of the animal was not noted in this passage, other than the ambiguous reference to "many" days. While bilateral vagotomy is lethal, the cutting of one vagus nerve is not. In Cruikshank's first experiment one of the vagus nerves (the eighth nerve in the system of cranial nerve numbering he used) ${ }^{6}$ was cut in the neck of a dog and a piece some $15 \mathrm{~mm}$ in length removed. Also included was the accompanying intercostal (sympathetic) nerve, but this was recognized as having no lethal effects when cut. Soon after nerve transection the animal experienced some difficulty in breathing and an inflammation of the eye on the side cut was noted. Within several days those changes passed off and by the eighth day the animal appeared to have recovered fully. Cruikshank then removed a section of the vagus (and the accompanying sympathetic nerve, as well) from the opposite side. Breathing became more laboured, the animal vomited and copious salivation from the mouth took place. The pulse rose. Later, the animal ate and drank and passed stools but seven days after the second operation, the animal died. The lethal effect was ascribed to the transection of the two vagus nerves for it was known that cutting the sympathetic nerves had no such effects. The significant observation made by Cruikshank on

4 S. Ochs, 'Waller's concept of the trophic dependence of the nerve fiber on the cell body in the light of early neuron theory', Clio Medica, 1975, 10: 253-265.

${ }^{5} \mathrm{~T}$. Willis, The description and uses of the nerves, 1681. Reprinted in W. Feindel (ed.), The anatomy of the brain and nerves, Montreal, McGill University Press, 1965.

- In our present terminology, twelve cranial nerves are designated with the vagus listed as the tenth (counting back from the most anterior pair of olfactory nerves). The identification and numbering of nerves is given by C. W. Rucker, 'History of the numbering of the cranial nerves', Mayo Clin. Proc., 1966, 41: 453-561. For Galen there were seven pairs with the glossopharyngeal, vagus and accessory nerves grouped as the sixth nerve. The most anterior nerve designated was the optic. See also, E. S. Smith, 'Galen's account of the cranial nerves and the autonomic nervous system', Clio Medica, 1971, 6: 77-98, 173-194. The term "pneumogastric" nerve was often employed as a synonym for the vagus nerve. 


\section{History of nerve regeneration}

examination of the nerves later removed from the animal was that a substance of the same colour as nerve appeared to unite the two ends. The cut ends also showed swellings which Cruikshank described as being rounder in form than that of a ganglion. The nerve on the opposite side which had been cut later also had a similar substance uniting the cut ends but it appeared somewhat more bloody. Cruikshank inferred from those observations that the substance uniting the cut ends was regenerated nerve, a circumstance "never heretofore observed". He wrote. "it occurred to me that it might be objected to the reasoning, that the first two nerves [vagus and sympathetic] on the right were doing their office before the last two [those on the left] were divided." Pursuing this thought, Cruikshank considered that the time allowed for regeneration had been too short: "The nerves had not yet acquired the power of performing their office". Therefore in his next experiment, Cruikshank cut the right vagus nerve of a dog and waited for three weeks before cutting the left vagus nerve. Vomiting with convulsive jerks of the abdominal muscles in breathing was again seen, but this soon subsided and the animal survived for a period of two and a half weeks before it died. The nerves which had been first divided were now found to be firmly united with what he referred to as a "kind of callous" substance, and which he analogized to the material found in the healed part of a broken bone.

The divided nerves of the right side were firmly united; having their extremities covered with a kind of callous substance; the regenerating nerve, like bone in the same situation, converting the whole of the surrounding extravasated blood into its own substance. The nerves of the left side were also perfectly united; but the quantity of extravasated blood having been less, the regenerated nerves were smaller than the original; I observed too, that they did not seem fibrous like original nerves, but the recollection that the callous of bone is dissimilar to the original bone, quieted whatever doubts could arise from this circumstance. ${ }^{8}$

The nerves removed from the animal were stored as an exhibit in Hunter's museum (Figure 1). ${ }^{9}$ Several years later, in 1778, the Abbé Fontana paid a visit to Hunter's laboratory and Cruikshank related his experiments on nerve regeneration and showed Fontana the preparation. ${ }^{10}$ When Fontana inquired as to Hunter's opinion of his experiments, Cruikshank "told me ingenuously, that the doctor did not perceive a real reproduction of the nerve in these experiments, and suspected very strongly, from the great difference betwixt the external structure of the part cut, and that of the other parts, that it was not the case."11 Fontana had some years earlier studied the effect of cutting sciatic nerves without observing evidence of nerve regeneration

' Cruikshank, op. cit., note 1 above.

Ibid.

- The preparation was identified by Kennedy and pictured in his review (op. cit., note 53 below). Mr. Donald F. Hay, Chief Technician in the Glasgow Department of Pathology in the Royal Infirmary, Glasgow, kindly sent a recent photograph which is pictured in Figure 1. It is given as specimen E. 38 housed in the Royal Infirmary Musuem and listed in the Hunter Museum catalogue as item 22.30 (op. cit., note 3 above, p. 209).

${ }_{10} \mathrm{~F}$. Fontana, Treatise on the venom of the viper; on the American poisons; and on the cherry laurel and some other vegetable poisons to which are annexed, observations on the primitive structure of the animal body; different experiments on the reproduction of the nerves; and a description of the nerves; and a description of a new canal of the eye, trans. from the French by J. Skinner, 2 volumes, London, Murray, 1778.

11 Ibid., vol. 2, p. 204. 


\section{Sidney Ochs}

and Cruikshank's revelations inspired him to make a further experimental study to investigate what, until then, he considered an unlikely possibility. Fontana's contribution was that he was able to make a microscopic examination of the regenerated nerve, an advanced technique for that time. In one series of experiments, he removed a portion from the vagus nerves of a dozen rabbits and some time later found that the ends were united. Fontana concluded from his microscopical study of the material found between the cut ends that it was indeed regenerated nerve. As evidence in support of that idea he had observed nerves normally to have a "spiral" or "banded" appearance and that same banding was found present in the material bridging the ends of the previously cut nerve. However, the time allowed by Fontana was not enough for the regenerated nerve fibres to have matured to the point where they would have approached their normal diameter so as to show banding.

In a study recently carried out by Clarke and Bearn ${ }^{12}$ using a microscope of the type available to Fontana, the authors saw the banded appearance readily with a low degree of magnification in fresh nerve trunks and showed that it is due to the wavy disposition of the nerve fibres within their enveloping (perineural) sheaths. With a light source directed at a narrow angle along the axial direction, the raised portion of the wave of nerve fibres throws its shadow across the shallow part adjoining it, thus enhancing the banded appearance. ${ }^{13} \mathrm{~A}$ significant observation made by Clarke and Bearn in the course of their "practical history" investigations was that a similar banding can be seen in degenerated nerves. The explanation is that the endoneurial tubes remaining in the degenerated nerve retain the form of the normal fibres they had previously contained, including its wavy disposition. If the unmyelinated regenerating fibres find their way along or within the endoneurial tubes ${ }^{14}$ we may, thus, account for the picture given by Fontana. The banding of the normal fibres above the transected region would taper to the thinned region where the thinner regenerating fibres enter the endoneurial tubes, the fibres then continuing farther on into the distal degenerated part of the nerve.

A critical aspect of Cruikshank's observations must be considered, namely that the time he allowed for restoration of nerve function was actually insufficient for the regenerating nerve fibres to have reached the heart, lung, or the gastrointestinal tract. Also, Cruikshank was overly impressed by the apparent prolongation of the life of the animal from a day or so to a time of several weeks. In actuality, his too few observations fell within the range of survival later known to occur following bilateral vagotomy: animals might live on for as long as two or three weeks before succumbing. This was first suggested by Haighton's ${ }^{15}$ experiments. He divided the vagus nerve on the one side in a dog with, as had been reported by Cruikshank, relatively minor symptoms. Three days later, Haighton divided the vagus nerve on the other side and

12 E. Clarke and J. G. Bearn, 'The spiral nerve bands of Fontana', Brain, 1972, 95: 1-20.

18 The wavy disposition of the fibres allows for some protection when the nerve trunk is stretched. Even a mild stretch causes the banding to disappear in the fresh nerve. The wavy disposition of fibres is not seen in nerves prepared by the usual technique of fixation of tissues used for histological examination but is readily observed in freeze-substituted preparations (S. Ochs, 'Beading of myelinated nerve fibers', Exp. Neurol., 1965, 12: 84-95.

${ }^{14} \mathrm{~S}$. Ramón y Cajal, Degeneration and regeneration of the nervous system, 1928, trans. by R. M. May, 2 volumes, reprinted, Hafner, New York, 1968.

${ }^{16}$ Haighton, op. cit., note 2 above. 


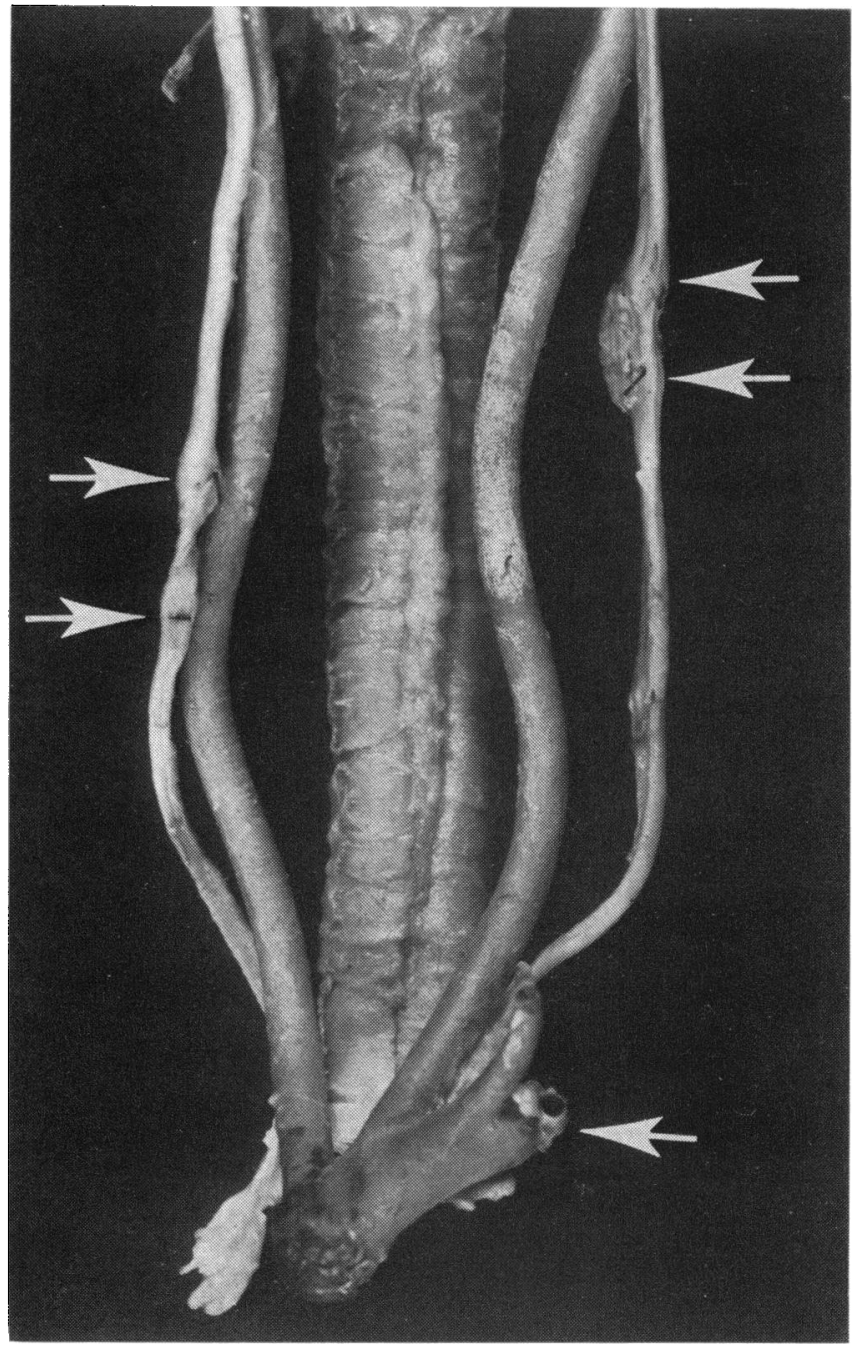

Figure 1

Cruikshank's preparation showing regeneration, preserved in Hunter's museum. The arrows on the right side show swellings above and below the previously cut trunk on the right. The preparation has been photographed from the posterior view. The nerve on the left which had been divided later also has arrows placed at the swelling near the original cut ends. Also shown by some of the arrows are the black pins inserted by Hunter. The lower arrow on the right shows the arch of the aorta with the carotids ascending on either side of the trachea. (Reproduced by courtesy of Mr. Donald F. Hays, Royal Infirmary, Glasgow.) 


\section{History of nerve regeneration}

death occurred four days later. So much was in accord with Cruikshank's findings. Haighton then prolonged the time between the two vagus nerve transections. When the second vagus nerve was cut nine days after the first, the animal died, but after a delay of thirteen days. This "prolongation" of the animal's life was taken by Haighton to indicate a "partial regeneration" of nerve in opposition to the complete regeneration which Cruikshank had supposed to be the case.

Haighton then performed his critical experiment. The vagus on the one side was divided, and six weeks were allowed to lapse before cutting the vagus nerve on the other side. The effect on the animal's physiological state was much less than that found after making the second vagal nerve transection at a shorter interval. The animal refused solid food, at first taking only milk. Six months later, however, recovery was complete and the animal lived on for a further nineteen months. To prove that the animal's longevity was due to a regeneration of the vagus nerves, rather than the possibility that another set of nerves had taken over the function of the vagus nerve, Haighton cut the vagus nerves he had previously transected. If the vagus nerves had regenerated, the second transection should result in a repetition of the effects usually seen following a bilateral vagotomy; namely, the animal should expire within a few days. If, however, some other nerves had assumed the office of the vagus, the re-cutting of that vagus nerve should have no untoward effect. When the vagotomy was again done above the original transection site, the usual acute symptoms were seen and the animal died on the second day. This therefore was taken as evidence for a true regeneration of the vagus nerve. Haighton dissected out the regenerated part of the nerve and concluded that it was united anatomically with what was indeed nerve tissue. However, that judgement rested on only one experiment. Additional support was soon forthcoming from Prévost's work. ${ }^{16} \mathrm{He}$ showed in kittens that a delay in cutting the second vagus for even up to one or two months was insufficient for a "full" nerve regeneration to take place. However, when four months was allowed between successive vagal transections, the animals lived on for fourteen days. Prévost showed by his microscopical studies that this was truly a nerve regeneration. A collateral reinnervation from other nerves taking on the function of the vagus was shown not to be the case by again cutting both the vagus nerve above the regenerated level as Haighton had done, with the death of the animal occurring soon after.

\section{THE LETHAL EFFECT OF VAGOTOMY}

The modern reader is struck by the ready acceptance of the lethality resulting from a double vagotomy, a phenomenon no longer dealt with in present-day textbooks of physiology. Perhaps this is because vagotomy is often performed at a lower level as a treatment for peptic ulcers. ${ }^{17}$

16 [J. L.] Prévost, 'Uber die Wiedererzeugung des Nervengewebes', Froriep's Notizen, 1827, 17: 113-115.

${ }^{12}$ A useful review of vagotomy as applied to medicine with little approbation for experimental work done much before 1900, is given by W. C. Alvarez, 'Sixty years of vagotomy; a review of some 200 articles', Gastroenterology, 1948, 10: 413-441. In its clinical application, vagotomy is performed by cutting the nerves subdiaphragmatically, below the innervation of the oesophagus. (L. R. Dragstedt, 'Vagotomy for gastroduodenal ulcer', Ann. Surg., 1945, 122: 973.) The effect of the operation is to reduce acid secretion and gastric motility. (F. J. Ingelfinger, 'Esophageal motility', 


\section{Sidney Ochs}

The reason for the lethal effect seen following transecting of both vagal nerves in the neck was investigated by a number of leading physiologists in the nineteenth century. ${ }^{18}$ Schiff ${ }^{19}$ considered the vagus to have a trophic effect on the lungs with vagotomy leading to a "nutritional" defect of the lungs-inflammation and death of the animal. An alternative possibility was that the lung changes following division of the vagus nerves resulted from an aspiration of saliva or perhaps a regurgitation of stomach contents into the lungs. Claude Bernard ${ }^{20}$ provided experimental evidence against the latter possibility by inserting a tracheal cannula into animals before cutting the vagi. In rabbits so prepared, death occurred as usual a few days after bilateral vagotomy. An entry was made in the stomach of two dogs to remove and also divert their contents before producing a bilateral vagotomy. Again, those animals died as usual thirty-six and forty hours later with, in one animal, clear lungs and with some emphysema present in the other. Bernard considered that the emphysema was caused by the increased depth of respiration seen following vagotomy with subsequent traumatization of the over-extended lungs. In support of this idea Legallois ${ }^{21}$ reported that the lungs of rabbits dying after vagotomy were congested and no longer able to float in water, an observation earlier noted by Cruikshank. However, Blainville ${ }^{22}$ found little effect of vagotomy in the lungs of pigeons dying after bilateral vagotomy. Blainville emphasized the digestive system changes seen in vagotomized mammals and birds.

As yet we do not have a complete explanation for the early occurrence of death following bilateral vagotomy but it appears likely that the paralysis of the oesophagus and altered gastrointestinal function is of critical importance. The effects of bilateral vagotomy were studied in the author's laboratory, duplicating as much as possible the approach of the early investigators except that aseptic technique was used and antibiotic treatment given to prevent infection. Either bilateral vagotomies or vagotomies performed at different intervals were performed on some thirty-five cats, dogs and rabbits. Deaths occurred from a few days to within two or three weeks afterwards. The longer survival times were commonly seen when the vagotomy was carried out in two stages. Gastrointestinal effects were most commonly seen and some of our observations suggest that electrolyte imbalance following gastrointestinal disturbance leads to a circulatory collapse as the immediate cause of death. Our experiments have served to indicate that the problem is a real one and that the effects seen by the early investigators cannot be put down to faulty technique as suggested, for

Physiol. Rev., 1958, 38: 532-584.) A summary of the effects of vagotomy with an investigation of the paralysis of oesophageal propulsion can be found described in the experiments of John Reid, 'An experimental investigation into the functions of the eight pair of nerves, or the glossopharyngeal, pneumogastric, and spinal accessory', Edinb. med. surg. J., 1838, 134: 1-68, pp. 46-47.

18 O. Frey, Die pathologischen Lungenveranderungen nach Lähmung der nervi vagi, Leipzig, Engelmann, 1877.

10 J. M. Schiff, Lehrbuch der Muskel- und Nervenphysiologie Lahr, Schauenburg, 1858-1859, pp. $410-411$.

${ }^{20}$ C. Bernard, Leçons sur la physiologie et la pathologie du systeme nerveux, 2 vols., Paris, Baillière 1868 , p. 369. 1812.

'1 J. J. C. Legallois, in op. cit., note 19 above, p. 352; Expériences sur la principe de la vie, Paris,

22 H. M. Ducrotay de Blainville, Extraites d'un essai sur la respiration, suivies de quelques expériences sur l'influence de la huitieme paire de nerfs dans la respiration, Paris, Didot, 1808. 


\section{History of nerve regeneration}

example, by Alvarez, ${ }^{23}$ or to infection.

\section{OUTGROWTH VERSUS REUNION AS THE BASIS OF REGENERATION}

Death following a double vagotomy, as indicated above, occurs at some variable time afterwards, making it difficult to use this preparation for systematic studies of nerve regeneration. The use of the sciatic nerve proved to be a most satisfactory preparation for such studies. Fontana, as noted, was unsuccessful in his early attempts to observe regeneration in the sciatic nerve. He considered it likely that the failure of regeneration was due to "too much motion in the parts where they are situated, and it would in all likelihood ensue if that motion were diminished". ${ }^{24}$ Alternatively, Fontana raised the possibility that there was an inherent difference between the vagus and the sciatic nerve with respect to its capability of regeneration, "a property only belonging to those nerves most essential". Those investigators who later turned to the sciatic nerve and showed its capability of regeneration thus helped establish the phenomenon of regeneration as a general property of nerve.

Müller ${ }^{25}$ used the sciatic nerve to good advantage in his studies of nerve regeneration. On dividing the sciatic nerve of rabbits he found a loss of sensation in the lower leg and a lack of movement on stimulating the nerve above the transection with electrical current from a battery comprising a "single pair of plates". When a "battery of 100 pairs of plates" was used, strong leg muscle contractions were elicited but this Müller traced to an adventitious spread of current rather than to an excitation and a conduction by the regenerated nerve fibres. Only a feeble contraction was found when the nerve was stimulated below the level of nerve transection, even with a thirty-plate battery. As shown by the microscopical examination of the sciatic nerves of the frog by Schwann, Müller's assistant at the time, they were clearly seen to have regenerated three months after making a transection. Some other observations of Schwann's are of interest. He found in the previously divided part, "nervous fibrils" lying close together and running the whole length of the nerve. The site of union did not appear as white as a normal nerve because "the neurilemma was less perfectly reproduced". ${ }^{26}$ These observations are the forerunners of later studies of regeneration made by Waller and others (see below).

Schwann also had reported that after regeneration had taken place in the sciatic nerve of the frog, the cutting of the dorsal roots had no (reflex) effect to cause contraction, while on cutting the ventral roots the usual strong (twitch) contractions of the leg muscles were produced. Müller inferred from such findings, taking into account the work of Bell and Magendie, that motor, sensory and sympathetic nerves each regenerated so as to reconnect with motor, sensory and sympathetic nerve respectively. The alternative possibility that sensory fibres could regenerate into motor fibres and vice versa was not eliminated, however.

Steinrück ${ }^{27}$ studied the course of nerve regeneration by following the return of

23 Alvarez, op. cit., note 17 above.

24 Fontana, op. cit., note 10 above, p. 213.

${ }_{25} \mathrm{~J}$. Müller, Elements of physiology, trans. from the German by W. Baly, (2 volumes: vol. 1, 1838; vol. 2, 1842), London, Taylor \& Walton, vol. 1, p. 421.

${ }^{20}$ Ibid., p. 421.

27 C. O. Steinrück, De nervorum regeneratione, Berlin, Decker, 1838. Abstracted in Schmidt's Jahrbüch der In- und Ausland. Med., 1840, 26: 102-104. 


\section{Sidney Ochs}

sensation and motion. In all, he carried out fifty nerve experiments performed mostly on cats using the sciatic nerves, with some studies made on the vagus, infraorbitalus and hypoglossus nerves, and additionally, some made on frog sciatic nerve. Several nerves were simply cut, but in most cases a piece of nerve was removed. Steinrück noted that some functional recovery occurred after five weeks but that a full regeneration might require as long as one to two years. As earlier noted by Flourens, Steinrück found that motor nerves could be made to innervate foreign muscles. In chickens the nerves innervating the wing muscles were cut and crossed. After their regeneration, stimulation of a nerve gave rise to the movement expected of the nerve innervating the muscle. In the case of cross-innervated muscles, movement of the wing in the up or down direction was opposite to that usually expected. Steinrück also concluded that sensory nerves could not innervate muscle and vice versa.

One other conclusion of Steinrück's caused considerable confusion. He considered regeneration to involve a growth from the neurilemma of both cut ends which was aided by bringing them together. The exudate of "lymph" which was formed was the medium in which, or from which, the new primitive fibres became organized. Growth was thus considered to occur by a process of "reunion".

Steinrück's "reunion" concept fitted well with the "dualist" ideas regarding the form and nature of the neuron. ${ }^{28}$ Valentin, a key originator of the dualist position, believed that two kinds of nerve "elements" existed, the nerve fibre and the nerve cell body respectively. ${ }^{29}$ Nerve fibres were believed to arise by the union of individual cells, the Schwann cells. ${ }^{30}$ The other neural "element", the cell body, was analogized by Valentin to an egg. These two neural elements were found closely apposed to one another in the central nervous system where a special relation was thought to occur. ${ }^{31}$ In opposition to the dualist view, Remak ${ }^{32}$ took a "monist" position, viewing the nerve fibre as having its origin in the cell body, i.e. he took what might be called an "early neurone theory" position. The term "neurone" as we understand it today was introduced and its intention consolidated only at the end of the nineteenth century..$^{33}$

Those accepting a "dualist" position favoured Steinrück's "reunion" concept of regeneration of nerve fibres. This would naturally follow if the fibres originated by the joining of individual cells as was proposed by Schwann. On the other hand, regeneration viewed as an outgrowth of nerve fibres from the portion of fibre connected to the cell body was a view in accord with the "monistic" position. Eventually

28 Ochs, op. cit., note 4 above.

${ }^{20}$ G. Valentin, Uber den Verlauf der letzenden Enden der Nerven, Breslau, Barth, 1836; (and Ochs, op. cit., note 4 above).

${ }^{80} \mathrm{~T}$. Schwann, Microscopical researches into the accordance in the structure and growth of animals and plants, trans. from the German by H. Smith, London, Sydenham Society, 1847. Reprinted by Kraus Reprint Co., New York, 1969.

${ }^{21}$ Ochs, op. cit., note 4 above. The cell was viewed as the active generator of nerve force which circulated passively in the fibre. Cf. H. Van der Loos, 'The history of the neuron', Chapter 1, in, H. Hydén (ed.). The neuron, Amsterdam, Elsevier, 1967.

32 Ochs, op. cit., note 4 above, and R. Remak, Observationes anatomicae et microscopicae de systematis nervosi structura, Reims, Berolini, 1838.

${ }^{83} \mathrm{H}$. W. G. Waldeyer-Hartz, 'Ueber einige neure Forschungen im Gebiete der Anatomie des Centralnervensystems', Dtsch. med. Wschr., 1891, 17: 1213-1218, 1244-1246, 1267-1269, 1287-1289, 1331-1332; 1352-1356. 


\section{History of nerve regeneration}

as Waller ${ }^{34}$ appreciated, it implied some influence emanating from the cell body. A careful study of the degeneration of nerve fibres following their transection and separation from the cell body held the key to a resolution of the problem.

Nasse $^{35}$ was the first to describe the degeneration of nerve fibres just distal to a nerve transection. Early after transection the normally cylindrically-shaped fibres were seen to break up and then later to become absorbed. Still later, new fibres appeared in the distal degenerated part of the nerve. Nasse reported that these fibres were smaller in diameter than normal fibres and had a "different look". Guenther and Schoen ${ }^{36}$ corroborated the discoveries of Nasse and considered that the degenerative changes seen in the distal transected portion were the result of a separation of the nerve fibres from their connexion with its "central portion". However, they also believed that the regenerating primitive nerve fibres could arise from the distal and proximal ends of transected nerves, thus accepting the reunion concept. Stannius ${ }^{37}$ soon after found that the degenerative changes were not confined to the immediate neighbourhood of the transection as was reported to be the case in earlier studies, but that degeneration extended into the finest distal ramifications of the fibres. These were, however, isolated or partial observations. It remained for Waller ${ }^{38}$ clearly and convincingly to describe the general properties of nerve degeneration. On transecting the glossopharnygeal nerve in the frog, he traced the distal degenerated nerve fibres into the fungiform papillae of the tongue. The part of the nerve connected to the centre remained normal. And, in a classical study ${ }^{39}$ Waller separately cut the dorsal roots, the ventral roots, or the nerve distal to the dorsal root of the second cervical ganglion of kittens and established that the portions of the nerve fibres still connected to their cell bodies retained their normal appearance, while that part of the fibre separated from the cell bodies degenerated. From this he inferred that some influence is continually exerted from the cell bodies of the dorsal root ganglion supplying something needed by the sensory nerve fibres to maintain their viability. Similarly, he supposed cell bodies would be found present in the spinal cord, to perform this function for the motor nerve fibres. The trophic influence was viewed by Waller as a "rivulet supplied by a river", the forerunner of our modern understanding of axoplasmic transport of materials in nerve fibres. ${ }^{40}$

Waller's studies of the regeneration of fibres followed directly from his work on degeneration. He described a regeneration of new nerve fibres originating from the end of the nerve above a transection. The new fibres were reported as being much

34 Ochs, op. cit., note 4 above.

${ }^{25}$ Christian Friedrich Nasse, 'Ueber die veränderungen der Nervenfasern nach ihrer durchsshneidung', Müller's Archiv, 1839, 405-419, p. 413.

${ }^{26}$ [A. F.] Guenther and [J. M. A.] Schoen, 'Versuche und Bemerkungen über Regeneration der Nerven und Abhangigkeit der peripherischen Nerven von den Central-organen', ibid., 1840, pp. 270286, p. 282.

37 Hermann F. Stannius, 'Untersuchungen über muskelreizbarkeit', ibid., 1847, pp. 443-462.

88 A. V. Waller, 'Experiments on the section of the glossopharyngeal and hypoglossal nerves of the frog, and observations of the alteration produced thereby in the structure of their primitive fibres', Phil. Trans. R. Soc., 1850, 140: 423-429.

39 A. V. Waller, 'Septième mémoire sur le système nerveux', C. R. hebd. Acad. Sci. (Paris), 1852, 35: 301-306; 'Huitième mémoire sur le système nerveux', ibid., 35: 561-564; Nouvelle méthode anatomique pour l'investigation du systeme nerveux, Bonn, Georgi, 1852.

40 Ochs, op. cit., note 4 above, p. 261. 


\section{Sidney Ochs}

smaller, one-quarter to one-eighth the normal diameter, pale without the double contour indicative of myelination and with fusiform nuclei positioned at intervals along their length. ${ }^{41}$ These new regenerating fibres growing out into the distal stump lay among, but not within, the old fibres. At later times the new fibres were found at increasingly distal positions, just as would be expected of their slow centrifugal growth into the degenerated nerve. After a relatively long time, nine months in the case of fibres reinnervating the papillae of the frog's tongue, the new fibres eventually reached the papillae. Waller thus clearly described regeneration much as we essentially would today. The long time course he found for regeneration in the frog corresponds with its lower metabolism compared to the mammal.

We might suppose that with such a clear description, Waller's studies would be confirmed and the reunion concept set aside. Unfortunately, that was not to be the case. The reunionists received fresh support from clinical observations. Paget ${ }^{42}$ recounted experiences which seemed to demand a reunion of nerve fibres. One of his cases was that of a boy in whom the median and radial nerves had been divided a little above the wrist. The nerves were not sutured but nevertheless, function in the hand which had been totally lost directly after the injury began to return in ten days and was nearly perfect in a month. Another case described by Paget was that of a boy whose hand had been almost severed from the forearm at the wrist with the median and radial nerves divided. After their surgical apposition sensation returned in ten to twelve days. These cases were referred to as examples of healing by "immediate union" or "primary adhesion". Obviously, such quick recovery could not be due to the regeneration of nerve fibres described by Waller.

Powerful experimental support for the concept of reunion was added by Schiff. ${ }^{48}$ In cats and dogs, he found similarly quick recoveries of function after nerve transections which he considered could only be due to reunion. Schiff believed that the sheath of Schwann and the axis cylinder (axon) remained viable in the distal segments of the transected nerves while the myelin undergoes degeneration. He proposed that the new regenerating fibres which Waller had reported were, in fact, the axis cylinders of fibres. These would be better seen after the fibres were deprived of their myelin. On transecting the lingual and infraorbital nerves Schiff found fascicules of normal appearing fibres in the distal nerve portions three to four weeks later. He interpreted this as due to a reunion with a rapid restoration of the myelin inside the sheaths of Schwann. Bruch ${ }^{44}$ also found a quick recovery of function after dividing the sciatic nerves of cats, and added support to the concept of reunion. In a number of cases he found no trace of scarring at the site of transection except for a slight constriction of the sheath of Schwann revealed by stretching the nerve. Lent ${ }^{45}$ considered that

¿A. V. Waller, 'Nouvelles recherches sur la régénération des fibres nerveuses', $C$. R. hebd. Acad. Sci. (Paris), 1852, 34: 675-679.

$42 \mathrm{~J}$. Paget, Lectures on surgical pathology delivered at the Royal College of Surgeons of England, rev. and ed. by Wm. Turner, London, Longman, 1863, vol. 1, p. 282.

4s $M$. Schiff, 'Sur la régénération des nerfs et sur les altérations qui surviennent dans des nerfs paralysés', C. R. hebd. Acad. Sci. (Paris), 1854, 38: 448-452.

" C. Bruch, 'U'ber die regeneration durchschnittenen nerven', Zt. wiss. Zool., 1855, 6: 135-138, p. 136.

${ }^{45}$ E. Lent, 'Beitrage zur Lehre von der Regeneration durchschnittener Nerven', ibid., 1856, 7: 145-153, p. 152. 


\section{History of nerve regeneration}

the myelin underwent degeneration in the distal transected part of the fibres leaving behind empty sheaths of Schwann and the nuclei previously hidden by the myelin but he went further than Schiff in holding that the axis cylinders reverted to an embryonic form. After its reunion with the upper portion of axis cylinders, the embryonic axis cylinder became regenerated and then it re-formed the myelin sheath.

Philipeaux and Vulpian ${ }^{46}$ introduced a yet more radical notion. They considered that the axis cylinders in the nerve fibres distal to a transection remain viable after the myelin degenerates. The axis cylinder could then later by itself bring about regeneration without a reunion with the central portion of nerve. The regenerated fibres were reported to have at first a small diameter, gradually increasing in size as regeneration proceeds. They made their observations on resected portions of hypoglossal nerve eighty-four days after transection; the sectioned portion of the nerve was far removed from the rest of the central portion of nerve and apparently not influenced by it. In another case, the distal amputated part of the nerve was examined forty-seven days after section and it also showed young fibres present among degenerated fibres without apparent reunion. Many months were required for full regeneration. A lack of response to electrical stimulation of the amputated nerve sections was taken by Philipeaux and Vulpian to indicate a stage where there was a "lack of irritability". On stimulating the distal regenerated part of a hypoglossal nerve even four months after transection, no contraction of the muscle was seen. Similar results were reported for lingual, sciatic, and median nerves in the frog, dog, and guinea pig. Yet, microscopical examination of the nerve showed the presence of numerous new "in situ regenerated" nerve fibres. The regenerating nerves only regained their power of irritability when the myelin was fully regenerated and a full return of function was then evidenced by the muscle contractions seen in response to nerve stimulation. The failure of Philipeaux and Vulpian to stimulate the newly regenerated nerves most likely can be analogized to phenomenon later studied by Erb and called by him the "degeneration reaction". ${ }^{47}$ In the early period of regeneration before the fibres have fully maturated, motor nerve fibres can conduct impulses to the muscle and produce contractions but the smaller regenerated fibres with their much higher threshold to electrical stimulation would appear to be inexcitable.

Opposition to Philipeaux and Vulpian's interpretation came quickly. Ranvier ${ }^{48}$ pointed out that fine strands of nerve fibres growing into the isolated piece of nerve might very well have been missed by Philipeaux and Vulpian. In answer, the latter attempted to dispose of that possibility by cutting out a piece of nerve which when examined forty-six days later, showed no reunion. This portion of nerve was again divided into proximal and distal parts and later numerous new fibres were found in both the distal and central portions. They again concluded that "nerves, motor or sensory, separated from their centers may remain isolated from their centers (and) recover their normal

46 J. Philipeaux and A. Vulpian, 'Note sur des expériences démontrant que les nerfs séparés des centres nerveux peuvent après être altérés complètement se régénérer tout en demeurant isolés de ces centres, et recouvrir leurs propriétés physiologiques', C. R. hebd. Acad. Sci. (Paris), 1859, 59: 507-509.

${ }^{47}$ W. Erb, Handbook of electro-therapeutics, trans. from the German by L. Putzel, New York, William Wood, 1883, pp. 75-76.

${ }^{48}$ M. L. Ranvier, Leçons sur l'histologie du système nerveux, 2 volumes, Paris, Savy, 1878-1879, pp. 270-278. 


\section{Sidney Ochs}

structure and physiological properties". ${ }^{99}$ While Philipeaux and Vulpian did concede that nerve reunion might speed up the process of regeneration, they held that the final character of the restoration remained the same. Eventually Vulpian ${ }^{50}$ retreated from his earlier position and denied the possibility of an autonomous regeneration of the nerve, but their work acted to strengthen the reunionist point of view.

\section{LATER VIEWS ON REGENERATION BY REUNION}

Ten years after his clear description of regeneration as due to an outgrowth of new fibres, Waller in effect accepted a reunionist view of regeneration in a review of nerve properties given at the Royal Institution:

... the upper end of the nerve, that is, the portion connected with the Centres, remains unchanged, except just at its lower extremity where it swells out and an albuminous fluid, like the white of an egg, exudes around and between it and the upper end of the lower extremity, in which, after a few days, we may already detect some small new nerve-fibres.

If this process of reparation is allowed to go on without interruption, the divided ends become in time united by this albuminous exudation, and the new nerve-fibres in the latter, uniting with the unchanged ones in the upper and the renovated ones in the lower end, serve to re-establish their continuity, and the nerve recovers its original structure-not as it would appear at first sight, and, as I first supposed, from the creation of new fibres in the lower end of the nerve; but simply from the formation of a fresh quantity of white medullary substance in the tubular membrane of the fibres and around their axis-cylinder, both of which remain unchanged throughout the whole process. ${ }^{\text {s1 }}$

He made an analogy of the nerve fibre to an electrical cable. "The central axis cylinder growing out to rejoin the axis cylinder of the amputated part becomes rejoined as in a cable where the copper wires become joined by soldering them together". Extending the analogy to other electrical properties:

There is another point, in which the analogy between the two agencies is close. The activity of the voltaic cell depends in a great measure upon the readiness with which the fluid element of the circuit undergoes decomposition-upon the readiness, that is, which the constituents of the fluid exhibit to take on new relations. The fluid is, in fact, the source of power in the cell. Now, although we cannot positively assert that the activity of a nerve-fibre depends upon the decomposability of its medullary substance, the readiness with which that substance undergoes decomposition indicates in it considerable activity of nutrition, however paradoxical to those who are unacquainted with physiology such a statement may appear. And activity of nutrition in the animal economy is invariably accompanied by potential energy: wherever power is most actively exhibited, there the metamorphosis of the tissues is proportionately rapid. Hence, it is only reasonable to look upon this medullary constituent of the nerve-fibres as the source, in the activity of its nutritive changes, of the peculiar powers which the fibres possess, or, at least, as the condition of the exercise of those powers. In connection with this point it may be mentioned that we have never been able to demonstrate in the grey variety of nerve-fibres, either in man or the lower animals, that power of conducting sensations and motor impulses which the white fibres possess; and in the grey fibres, it will be remembered, the medullary substance is absent. That those fibres do exercise functions of some kind there can be no doubt; but what those functions may be we are at present unable to say. ${ }^{52}$

10 J. Philipeaux and A. Vulpian, 'Recherches expérimentales sur la régénération des nerfs séparés des centres nerveux', Mém Soc. Biol. (Paris), 1859, p, 345.

${ }_{50}$ A. Vulpian, Leçons sur la physiologie générale et comparée du système nerveux, Paris, Baillière, 1886 (see also, op. cit., note 14 above, vol. 1, p. 9).

${ }^{51} \mathrm{~A}$. V. Waller, The nutrition and separation of nerves; being the substance of a lecture delivered at the Royal Institution of Great Britain, Friday, May 31 1861, London, Read, 1861.

${ }^{52}$ Ibid. 


\section{History of nerve regeneration}

In this interesting passage, Waller presciently discusses the relation of nutrition to nerve function. He also makes reference to the observation that electrical stimulation of the grey (sympathetic) fibres does not give rise to either sensation of motor responses and that they are thus inexcitable as is apparently also the case for newly regenerated fibres. This was difficult to interpret. As pointed out above, we can account for this by the high thresholds of these fibres to stimulation.

With the weight of experimental evidence available at the time supporting reunion, we should perhaps not be surprised that even at the end of the nineteenth century, Kennedy ${ }^{53}$ on reviewing the history of regeneration took a reunionist position. He was also moved to this by his own clinical experiences. He cited cases where sensation returned within two to five days following severance of nerves in the forearm. Localization was also recovered a short time later and then voluntary motion, though this imperfectly. He thought the rapid recovery was incompatible with a regrowth of fibres. Delays and shortcomings in the course of recovery of motor function were accounted for by atrophic changes in the muscles. From this point of time we have no clear explanation for those cases of early returns of function described by Kennedy and such noteworthies as Laugier, ${ }^{54}$ Paget $^{55}$ and others.

A still stronger support was given to reunionism by Bethe ${ }^{56}$ and others at the turn of the century who appeared to confirm the experiments of Philipeaux and Vulpian and who vigorously maintained the view that the nervous system comprised a "reticulum" rather than being composed of neuronal units.

The challenge to neuronal doctrine by Bethe and his camp stimulated Ramón y $\mathrm{Cajal}^{57}$ to his decisive studies supporting the neuron doctrine. Cajal considered that his studies on regeneration reaffirmed Waller's (earlier) law of regeneration in that new fibres sprout and grow from the upper portion of transected fibres. But this story is best left to the lively description given by Cajal himself. With the close of that chapter we are in the modern era.

\section{SUMMARY}

Cruikshank, in 1776, was the first to suggest that cut nerves could regenerate and resume their function. It was known that the cutting of both the vagus nerves in the neck leads to the death of an animal within several days. He found that cutting the nerve in the neck of a dog on one side only was not lethal and that if some time were allowed before cutting the other vagus nerve, life was prolonged. The ends of the vagus appeared to Cruikshank to have become united by a growth that looked like regenerated nerve substance and the subsequent microscopic investigations of Fontana supported that view.

The variability in the time of death of animals following vagotomy hampered the early investigators who used it as an index of nerve regeneration. We now know that

68 R. Kennedy, 'Degeneration and regeneration of nerves: an historical review', Proc. R. phil. Soc. Glasg., 1898, 29: 193-229.

s4 M. Laugier, 'Note sur la suture du nerf median', C. R. hebd. Acad. Sci. (Paris), 1864, 58: 11391144.

s5 Paget, op. cit., note 42 above.

so A. Bethe, Allgemeine Anatomie und Physiologie des Nervensystems, Leipzig, G. Thieme, 1903.

${ }^{67}$ Ramón y Cajal, op. cit., note 14 above, pp. 3-26. 


\section{Sidney Ochs}

the times allowed for full return of function were inadequate in those early studies. The causes of death following vagotomy are multiple and some remain unknown even today. The sciatic nerve proved a much more suitable preparation for investigations of regeneration. The return of sensory and motor function could be studied and in addition microscopic observations of cut and regenerated nerves carried out. Those studies soon led to two opposing interpretations of how regeneration comes about-whether by an outgrowth of new fibres from the portion of the cut nerve still connected with the cell body, or through a "reunion" of the two cut ends of the nerve. These two positions had a relation to the two contending concepts of nerve in existence throughout most of the nineteenth century; the "dualists" holding that nerve cell bodies and fibres were separate entities each of independent origin, the "monists", in an early form of neurone doctrine, that the fibres took their origin from the cell body.

Throughout the last half of the nineteenth century most animal experimental studies and the clinical data both seemed to favour the "reunion" concept of regeneration until at the end of the nineteenth century the neurone doctrine as we know it was established and the outgrowth view became accepted.

The unfailing assistance of the librarians of the University of Indiana School of Medicine, Indianapolis, and the History of Medicine Division of the National Library of Medicine, Washington D.C., is gratefully acknowledged. 